\title{
PATIENT COUNSELING ABOUT HERBAL-DRUG INTERACTIONS
}

\author{
Md. Sarfaraj Hussain* \\ Faculty of Pharmacy, Integral University, Dasauli, Kurshi road, Lucknow-226026, Uttar Pradesh. India. \\ *Email: sarfarajpharma@gmail.com
}

\begin{abstract}
Many people have the mistaken notion that, being natural, all herbs and foods are safe; this is not so. Very often, herbs and food may interact with medications you normally take, result in serious reactions. During the latter part of this century the practice of herbalism has become mainstream throughout the world. This is due remove to the recognition of the value of traditional medical systems in the world. Herbal medicines are mixtures of more than one active ingredient. The multitude of pharmacologically active compounds obviously increases the likelihood of interactions taking place. Hence, the likelihood of herb-drug interactions is theoretically higher than drug-drug interactions because synthetic drugs usually contain single chemical entity. Case reports and clinical studies have highlighted the existence of a number of clinically important interactions, although cause-and-effect relationships have not always been established. Herbs and drugs may interact either pharmacokinetically or pharmacodynamically. The predominant mechanism for this interaction is the inhibition of cytochrome P-450 3A4 in the small intestine; result in a significant reduction of drug presystemic metabolism. An additional mechanism is the inhibition of Pglycoprotein, a transporter that carries drug from the enterocyte back to the gut lumen, result in a further increase in the fraction of drug absorbed. Some herbal products (e.g. St. John's wort) have been shown to lower the plasma concentration (and/or the pharmacological effect) of a number of conventional drugs including cyclosporine, indinavir, irinotecan, nevirapine, oral contraceptives and digoxin. The data available so far, concerning this interaction and its clinical implications are reviewed in this article. It is likely that more information regarding such interaction would crop up in the future, awareness of which is necessary for achieving optimal drug therapy.
\end{abstract}

Key words: Herbal drug, Herbal Preparation, herbal-drug interaction, drug-drug interaction, Cytochrome P-450

\section{Introduction}

Many medicinal herbs and pharmaceutical drugs are therapeutic at one dose and toxic at another. Interactions between herbs and drugs may increase or decrease the pharmacological or toxicological effects of either component. Synergistic therapeutic effects may complicate the dosing of long-term medications e.g. herbs traditionally used to decrease glucose concentrations in diabetes could theoretically precipitate hypoglycaemia if taken in combination with conventional drugs (Agrawal et al., 2006). Herbal medicines are ubiquitous: the dearth of reports of adverse events and interactions probably reflects a combination of under-reporting and the benign nature of most herbs used. Due to the increasing use of herbal and other dietary supplements, healthcare providers and consumers need to know whether problems arise by using these preparations in combination with conventional drugs (Smith et al., 2000). The use of herbal products has dramatically increased over the past decade, driving physicians to become educated in regard to potential herbal complications and drug interactions. From 1990 to 1997, the market of herbal product increased by $48 \%$, with $42 \%$ of the population using alternative treatments and spending an estimated \$27 billion on them (Eisenberg et al., 1998). Herbal products are widely available, relatively inexpensive, and often make alluring but unsubstantiated claims. Herbal medicine appeals to consumers who believe that natural herbal products are preferable to synthetic pharmaceuticals (Kaptchuk et al., 1998). Usually herbal preparations are well thought-out more safe than pharmaceutical drugs although there are some potential adverse reactions from taking both together (Schultz et al., 1998).

A relevant safety concern associated with the use of herbal medicines is the risk of interaction with prescription medications (Ernst et al., 2000). This issue is especially important with drugs having narrow therapeutic index such as warfarin or digoxin (Izzo et al., 2004). Recent examinations have indicated that as many as16\% of prescription drug consumers consume herbal supplements. Exacerbating the problem, herbal remedies are often marketed on the Internet with misleading and unproved claims. Despite repeated warnings, consumers continue to equate "natural" with safe. As use of herbal remedies become more prevalent and reports of adverse effects continue to mount, there arises a need to understand better about potential complications by the healthcare professionals. There are numerous products currently available in the markets that have been associated with toxicity. The aim of this article is to highlight the clinical interactions between herbal remedies and prescribed drugs. Here we present information regarding different approaches used to study the interaction of herbs and drugs that involve drug metabolizing enzymes and transporters. Theoretical herb drug interactions which are based on in vitro experiments, animal studies and speculative empirical evidence can be found elsewhere (Marechal1 et al., 2008). 


\section{Chemicals present in herbal products}

This is misconception among peoples using herbal products that, herbal preparations being natural in origin are good for human's health for safety point of view. There is little public awareness or appreciation of the fact that these "all natural" extracts are actually a combination of potentially biologically active compounds that exist in these marketed products in unknown quantities. The use of herbal products in the United States has skyrocketed in the past decade as a result of the patient's pursuit of finding an 'all natural' alternative to the conventional western medicine. Marketed herbal products contain structurally diverse chemicals and many of which either possess inherent pharmacological activity or even show possible toxicity. Among the more popular herbal products Milk thistle and St. John's wort are two popular herbal products marketed to treat liver disorders and depression, respectively (Jacobs et al., 2002, Rodriguez et al., 2003, Chavez et al., 2006). Several clinical studies and case reports have demonstrated the potential benefits of St. John's wort compared with conventional therapy in the treatment of mild to moderate depression (Linde et al., 1996, Wheatley et al., 1997, Hussain et al., 2009). Studies conducted in vitro and in vivo have shown that St. John's wort constituents inhibit the reuptake of neurotransmitters linked to depression in humans (Nathan et al., 1999). St. John's wort, an extract of the flowering portion of the plant Hypericum perforatum, is a mixture of a number of biologically active and complex compounds (Figure 1). At $0.3 \mathrm{mg}$ per capsule, the napthodianthrone, hypericin is used as a means of standardization of the marketed product.

Milk thistle [Silybum marianum (L.) (Family; Asteraceae)] extract is one of the most commonly used nontraditional therapies, particularly in Germany. Clinically, milk thistle is being studied as a therapy in the treatment of prostate cancer and has been used in the treatment of a variety of liver disorders. Milk thistle is known to contain a number of flavonolignans, compounds that are produced in plants by radical coupling of a flavonoid and a phenylpropanoid (Dewick et al., 1997). A mixture of these flavonolignans, termed silymarin, is known to be composed of mainly silybin (about 50-70\%), silychristin, silydianin other closely related flavonolignans (Wagner et al., 1986) (Figure 2). A standardized extract of milk thistle contains at least 70\% silymarin (Foster et al., 1999, Schulz et al., 2001). By above data it is clear that structurally diverse chemical constituents are present in herbal extracts. These chemicals must be eliminated from the body either through the kidney or through the liver.

\section{Biological description of Cytochrome P450}

The CYP enzymes involved in drug metabolism in humans are expressed predominantly in the liver. However, it is also present in intestines (both large and small), lungs and brain. They are insoluble proteins, bound to the endoplasmic reticulum with complex mechanistic and structural features. However, the first crystal structure of mammalian CYP enzymes have recently been determined namely CYP2C5, CYP2B4, CYP2C9 and CYP3A4 (Paul et al., 1996, Meunier et al., 2004) and thus, much progress can be expected in this area in near future. It is believed that 15-20 different CYP enzymes insofar contribute to drug metabolism in the human liver. However, the CYP enzymes 1A2, 2C9, 2C19, 2D6, 2E1 and 3A4 are considered most important among them (Werck et al., 2000, Degtyarenko et al., 1995, Guengerich et al., 2006, Guengerich et al., 1997). They have different yet complementary substrate specificities with ability to metabolize a vast array of xenobiotics. CYP3A4 acts on most lipophilic substrates and is known to metabolize more than $50 \%$ of the drugs in the liver (Munasinghe et al., 2002), whilst CYP2D6 exhibits a preference for positively charged molecules, usually with basic nitrogen. CYP2C9 metabolizes weakly anionic molecules, CYP1A2 metabolizes poly-aromatic hydrocarbons and CYP2E1 metabolizes small and soluble organics. Therefore, the CYP systems can metabolize almost any organic xenobiotic. Drugs can increase or decrease the activity of one or more CYP enzymes, which alters the rate at which the drug is degraded and cleared from the body. This can work in both ways. When a drug increases the activity of a CYP protein, CYP can render the drug ineffective, because it is cleared too quickly from the body. Alternatively, when a drug inhibits a CYP protein, CYP may not prevent the drug from accumulating to toxic levels, even to the extent of causing an overdose. CYP1, CYP2, CYP3 and CYP4 are most important for drug biotransformation among CYP proteins. CYP3A4 is the most prevalent in the body and is known to metabolize several drugs (Glue et al., 1999, Robertson et al., 2005, Warrington et al., 2005).

\section{Definition and classification of drug interaction}

Interaction is said to occur when the effect of one drug is altered by the presence of another drug(s), food or drink. (Stockley et al., 2002). When a therapeutic combination could lead to an unexpected change in the condition of the patient, this would be described as an interaction of potential clinical significance. The net effect of the combination may be synergism or additive effect of one or more drugs, antagonism or negative effect of one or more drugs, alteration of the effect of one or more drugs or the production of idiosyncratic effects (Grenier et al., 2003). A drug-drug interaction can be defined as the effect that one drug has on another. Drug-drug interactions can be pharmacokinetic or pharmacodynamic in nature (Nebert et al., 2002, Christians et al., 2005) and are not exclusive to the elderly population. Pharmacokinetics (what the body does to the drug) involve the effects of one drug on the absorption, distribution, metabolism, or excretion of another drug. These interactions can result in changes in serum drug concentrations which might alter the clinical response. The most frequent pharmacokinetic drug-drug interactions involve several isoenzymes of the hepatic cytochrome P450 (CYP) and drug transporters such as the P-glycoprotein and organic anion transporters (Bista et al., 2006, Lee and Stockley, 2003). Pharmacodynamics (what the drug does to the body) is related to the pharmacological activity of interacting drugs. The outcome is an amplification or decrease in the therapeutic effects or side-effects of a specific drug. 
<smiles></smiles>

Pseudohypercin $\mathrm{R}=\mathrm{OH}$ Hypercin R=H<smiles>CC(C)=CCCC1(C)C(CC=C(C)C)CC2(CC=C(C)C)C(=O)C(CC=C(C)C)=C(O)C1(C(=O)C(C)C)C2=O</smiles>

Hyperforin

Figure 1. Chemical structures of hypericin and hyperforin, biologically active constituents of St John'swort.<smiles>C=CC1=C(/C=C/[C@H]2Oc3cc(O)cc(O)c3C(=O)[C@@H]2O)O[C@@H](CO)[C@H](c2ccc(O)c(OC)c2)O1</smiles><smiles>COc1cc(-c2oc3c(O)cc([C@@H]4Oc5cc(O)cc(O)c5C(=O)[C@H]4O)cc3c2CO)ccc1O</smiles> 


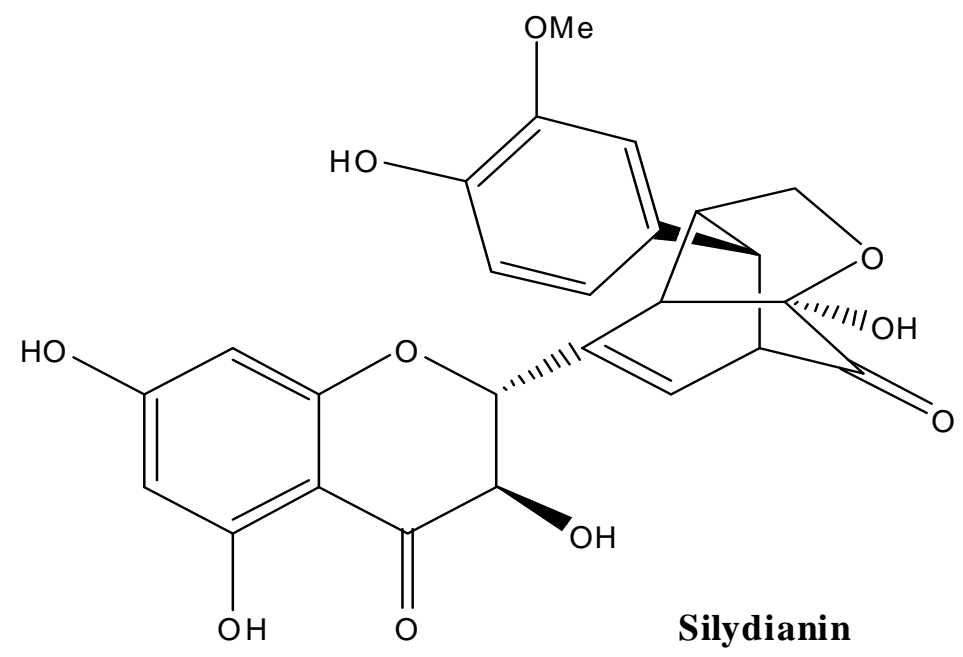

Figure 2. Chemical structures of silybin, silychristin, silydianin, biologically active constituents of Milk thistle.

\section{Type of drug interactions (DIs):}

Drug Interactions may be broadly classified as:

\section{Drug-disease interaction}

This type of drug interaction is associated in patients suffering from renal and hepatic impairment. Patient at high risk for drug-disease interactions include those suffering from aplastic anemia, asthma, cardiac arrhythmia, intensive care patients, diabetes, epilepsy and hypothyroidism. It is therefore essential to monitor the conditions and required doses of the drug to prevent serious repercussions (Lambrecht et al., 2000).

\section{Drug-herb interaction}

Several cases of possible herb drug interactions have been reported (Cupp et al., 1999). Herbal products can produce ADRs likely due to lack of standardization of content of natural products, variations in the strength of the active ingredient, contamination by fungal organisms and adulteration with other potentially harmful natural products (Chan et al., 1995). Some of the clinically significant drug-herb interactions reported or suspected is listed in the Table 1 . And examples of herbal medicine involved in drug interaction and their possible mechanism of interaction with the source of evidence are listed in Table 2.

\section{Drug-drug interaction}

This type of interaction is associated with both prescriptions as well as over-the counter (OTC) drugs. For example; Antibiotic Ciprofloxacin taken with antacids lowers its effectiveness. Similarly, Digoxin and Amiodarone combination leads to increased Digoxin toxicity. Among the different types of DIs, the DDIs are most common of their high incidence rate and the serious outcomes (Wijnands et al., 1987).

\section{Miscellaneous DIs}

This includes interaction of drug with dietary supplements, food and beverages, cigarettes etc. Component Vitamin $\mathrm{K}$ is present in many vegetables. It promotes production of blood-clotting factors that may reduce the effectiveness of anticoagulant drug like Warfarin. Many reports on reduction of the efficacy of Warfarin with intake of huge quantities of ice cream have been 
reported (Leon et al., 1971). Vitamin B6 (Pyridoxine) found in avocados, beans, peas, sweet potatoes, bacon, beef liver, pork, tuna and vitamin-mineral products increases the metabolism of Levodopa, producing decreased blood levels of Dopamine and is associated with parkinsonism symptoms (Jusko et al., 1979). Concurrent use of Theophylline and tobacco may result in decreased theophylline concentration. Theophylline doses may need to be reduced by $25 \%$ to $33 \%$ after discontinuation of tobacco smoking. Monitoring of theophylline plasma concentrations may be necessary to optimize therapy (Kruth et al., 2004, Yue and Jansson, 2001, Izzat et al., 1998, Tam et al., 1995, Jiang et al., 2004).

\section{Mechanism of herbal-drug interactions}

Herbal medicines follow modern pharmacological principles. Hence, Herb-drug interactions could be characterized either by pharmacokinetic (PK) or pharmacodynamic (PD) mechanisms. Pharmacokinetic interactions have been more extensively studied, and in-vitro and in-vivo studies indicate that the altered drug concentration by co-administered herbs may be attributed to the induction or inhibition of hepatic and intestinal drug-metabolizing enzymes, particularly Cytochrome P-450 (CYP)], and/or drug transporters such as P-glycoprotein (Boullata et al., 2005, Hussain et al., 1999). The CYP is the most important Phase I drug-metabolizing enzyme system, responsible for the metabolism of a variety of drugs. Many herbs (e.g. St. John's wort) and natural compounds isolated from herbs (e.g. flavonoids, coumarins, furanocoumarins, anthraquinones, caffeine and terpenes) have been identified as substrate inhibitors or inducers of various CYP enzymes (Dietary Supplement-A- 2005). Specifically, clinical studies have shown that long-term (2 weeks) administration of St. John's wort significantly induced intestinal and hepatic CYP3A4 and possibly other CYP enzymes involved in drugs metabolism. Moreover, a clinical study performed on 12 healthy subjects showed that Echinacea modulated the catalytic activity of CYP3A at hepatic and intestinal sites (induction of hepatic CYP3A4 and inhibition of intestinal CYP3A4). In contrast, a number of herbal medicines including Green tea, Ginkgo garlic, and Saw palmetto and Siberian ginseng do not affect CYP3A4 and CYP2D6 activities in normal volunteers. Pglycoprotein in the intestine, liver and kidney may play an important role in the absorption, distribution, or excretion of drugs. Pglycoprotein appears to limit the cellular transport from intestinal lumen into epithelial cells and also enhances the excretion of drugs out via hepatocytes and renal tubules into the adjacent luminal space. Like CYP, P-glycoprotein is vulnerable to inhibition, activation, or induction by herbs and herbal constituents. Hyperforin, a major ingredient of St. John's wort, binds to orphan pregnane X receptor, resulting in a series of intracellular events leading to the expression of CYP3A4 and P-glycoprotein. A few pharmacodynamic interactions have also been reported. Pharmacodynamic interactions may be additive (or synergetic), whereby the herbal drug potentiates the action of synthetic drugs (e.g. interaction between the anticoagulant warfarin with antiplatelet herb), or antagonistic, whereby the herbal medicine reduces the efficacy of synthetic drugs (e.g. kava possesses dopaminergic antagonistic properties and hence reduce the pharmacological activity of the anti-Parkinson drug levodopa) (Izzo et al., 2005).

\section{Determination of herbal-drug interactions Adverse event reporting (AER)}

Reports on adverse drug events are currently limited. The FDA maintains the Med Watch system for reporting adverse events, for both conventional drugs as well as dietary supplements. In 2002, 320860 adverse events were reported (Anon, 2002). However, the Med Watch system does not separate drug and herbal interactions. In addition, a report published by the Department of Health and Human Services (DHHS) estimated less than 1\% of all drug-dietary supplement interactions to be reported to the FDA (Anon, 2001). A published review of widely claimed interactions found that $<15 \%$ were well documented (Barnes et al., 1998) The lack of available clinical data for many herbal products serves as a barrier for post marketing safety assessment of herbal products.

\section{Nature of herbal-drug interactions}

Unlike conventional drug, most of the natural products are complex mixture of chemical constituents, which may or may not show any therapeutic activity. Often complete characterization of all the chemical constituents in a natural product is unknown. Additionally, chemical makeup of a natural product may vary, depending on the part of the plant processed (roots, stems, leaves, fruits), season and growing conditions.

Not only does the complex nature of natural products complicate the determination of drug-herbal interactions, but also the manufacturing procedures. Because herbal products are not regulated by the FDA, there are no standards for herbal products. Indeed, some products have been found to be misidentified, substituted and/or adulterated. Testing of the quality of more than 1200 dietary supplement products by the independent laboratory ConsumerLab.com found that 1 in 4 dietary supplement products, lacked the labeled ingredients or had other serious problems such as unlisted ingredients or contaminants. This creates a problem while evaluating the validity of drug-herbal interactions (Rodriguez-Landa et al., 2003). Herbal products are not regulated for purity and potency like other pharmaceuticals [Dietary Supplement Health and Education Act of 1994, Public Law No. 103-417, 1994]. Thus, there are possibilities that the adverse effect and drug interaction of herbal products could be caused by impurities (e.g., allergens, pollens and spores), batch-to-batch variability. Medical practitioners must be aware of herb-drug interactions, in order to avert deadly risks for patients. 
Table 1. Some clinically significant drug-herb interactions:

\begin{tabular}{|c|c|c|}
\hline Herbal drugs & Biological source & Interaction reported or suspected \\
\hline Ginkgo & Ginkgo biloba & $\begin{array}{l}\text { Concurrent use of ginkgo and nonsteroidal antiinflammatory } \\
\text { agents may result in an increased risk of bleeding and with } \\
\text { warfarin causes bleeding. (Meisel et al., 2003) }\end{array}$ \\
\hline Garlic & Allium sativum & $\begin{array}{l}\text { Concurrent use of garlic and anticoagulants result in increased } \\
\text { risk of bleeding. (Legnani et al., 1993) }\end{array}$ \\
\hline Ginger & Zingibar officinale & $\begin{array}{l}\text { Concurrent use of ginger and anticoagulants may result in } \\
\text { increased risk of bleeding, sulfa guanidine enhance absorption. } \\
\text { (Kruth et al., 2004) }\end{array}$ \\
\hline Ginseng & Panax ginseng & $\begin{array}{l}\text { Concurrent use of ginseng and antidiabetic agents may result in } \\
\text { increased risk of hypoglycemia. (Vuksan et al., 2000) }\end{array}$ \\
\hline St. John's wort & Hypericum perforatum & $\begin{array}{l}\text { Concurrent use of digoxin and St John's wort may result in } \\
\text { reduced digoxin efficacy. (Hennessy et al., 2003) }\end{array}$ \\
\hline St. John's wort & Hypericum perforatum & 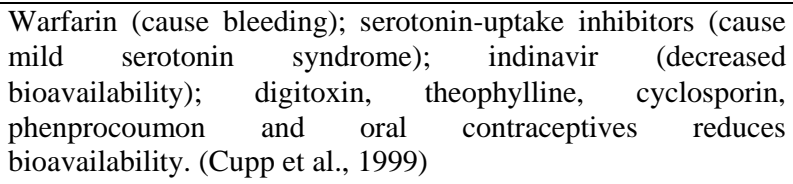 \\
\hline Rhubarb & Rheum officinale & $\begin{array}{l}\text { Cardiac glycosides and anti-arrhythmic agents potentiates by } \\
\text { reducing potassium via laxative effect. (Westendorf, 1993) }\end{array}$ \\
\hline Astragalus & Astragalus membranaceus & $\begin{array}{l}\text { Cyclosporine, azathioprine, methotrexate impair immuno- } \\
\text { suppressive effects. }\end{array}$ \\
\hline Licorice & Glycyrrhiza uralensis & $\begin{array}{l}\text { Corticosteroids and thiazide diuretics potentiating; digitalis or } \\
\text { other cardiac glycosides increases sensitivity (Mu et al.,2006) }\end{array}$ \\
\hline Ma-huang & Ephedra sinica & $\begin{array}{l}\text { With MAO inhibitors cause hypertension; cardiac glycosides or } \\
\text { halothane react to produce cardiac arrhythmia; caffeine } \\
\text { intensify cardiovascular side effects. }\end{array}$ \\
\hline Aloe & Aloe ferox & $\begin{array}{l}\text { Cardiac glycosides and antiarrhythmic agents potentiates by } \\
\text { reducing potassium via laxative effect (Westendorf, 1993) }\end{array}$ \\
\hline Salvia & Salvia miltiorrhiza & With warfarin cause bleeding (Gaddis et al., 2002) \\
\hline Bupleurum & Bupleurum falcatum & With sedatives potentiating effect \\
\hline
\end{tabular}

\section{Patient counseling about herbal-drug interactions}

Use of herbal and dietary supplements is extremely common. In US survey, adults who regularly take prescription medication, $18.4 \%$ of them reported the concurrent use of at least one herbal product or high-dose vitamin (and $61 \cdot 5 \%$ of those who used unconventional therapies did not disclose such use to their physicians). A survey of 515 users of herbal remedies in the UK found that $26 \%$ would consult their general practitioner for a serious adverse drug reaction associated with a conventional over-thecounter medicine, but not for a similar reaction to herbal remedy (Gorski et al., 2004). Clinicians must guide patients about use of herbs in a non-judgmental manner. The patient should be alerted for adverse reactions or interactions, and should be told about the proper use of herbal drugs (Mohammad et al., 2009). Formulation, brand, dose, and direction for use of herbs should be documented on the patient's charts and updated regularly. Patients with clotting disorders, those awaiting surgery, or those on anticoagulant therapy should be warned against the concurrent use of ginkgo, danshen, dong quai, papaya, or garlic. Many other herbs also contain anticoagulant substances as a precaution; patients on warfarin should have an INR measurement within a week of starting any herbal treatment. Patients on serotonin-reuptake inhibitors, cyclosporin, digoxin, phenprocoumon, or any critical chronic medication should avoid St John's wort; while those on phenelzine and tricyclic antidepressants should avoid ginseng and yohimbine respectively. There are still undoubtedly many undiscovered interactions 
Hussain Afr J Tradit Complement Altern Med. (2011) 8(S):152-163

Table 2: Examples of herbal medicine involved in drug interaction and their possible mechanism of interaction:

\begin{tabular}{|c|c|c|c|c|c|}
\hline Drug & Herb & $\begin{array}{l}\text { Result of } \\
\text { interaction }\end{array}$ & Possible mechanism & $\begin{array}{l}\text { Source of } \\
\text { evidence }\end{array}$ & Reference \\
\hline Alprazolam & St John's wort & $\begin{array}{l}\text { Decreased plasma } \\
\text { levels Alprazolam }\end{array}$ & $\begin{array}{l}\text { Alprazolam is a specific } \\
\text { probe for CYP 3A4, } \\
\text { which is induced by St } \\
\text { John's wort. }\end{array}$ & $\begin{array}{l}\text { Clinical } \\
\text { studies }\end{array}$ & $\begin{array}{l}\text { Jiang et al., } \\
\text { 2004, Schmider } \\
\text { et al ., } 2002\end{array}$ \\
\hline Amitriptyline & St John's wort & $\begin{array}{l}\text { Decreased plasma } \\
\text { levels of the drug }\end{array}$ & $\begin{array}{l}\text { Amitriptyline is a } \\
\text { substrate of both } \\
\text { CYP2C19 and P- } \\
\text { glycoprotein which is } \\
\text { induced by St John's } \\
\text { wort. }\end{array}$ & $\begin{array}{l}\text { A clinical } \\
\text { study }\end{array}$ & $\begin{array}{l}\text { Dannawi et al., } \\
2002\end{array}$ \\
\hline Buspirone & St John's wort & Hypomania & $\begin{array}{l}\text { Synergistic effect on 5- } \\
\text { HT receptor. }\end{array}$ & $\begin{array}{l}\text { A case } \\
\text { report }\end{array}$ & $\begin{array}{l}\text { Gorski et al. } \\
2004\end{array}$ \\
\hline Aspirin & Ginkgo & $\begin{array}{l}\text { Spontaneous } \\
\text { hyphema }\end{array}$ & $\begin{array}{llr}\text { Additive } & \text { effect on } \\
\text { platelet } & \text { aggregation; } \\
\text { ginkgolides } & \text { show } \\
\text { antiplatelet activity } & \end{array}$ & $\begin{array}{l}\text { A case } \\
\text { report }\end{array}$ & Leon et al., 1971 \\
\hline Lovastatin & $\begin{array}{l}\text { Pectin or oat } \\
\text { bran }\end{array}$ & $\begin{array}{l}\text { Decreased } \\
\text { absorption } \\
\text { Lovastatin }\end{array}$ & $\begin{array}{l}\text { Pectins or bran fibres } \\
\text { may bind or trap } \\
\text { lovastatin in the gut. }\end{array}$ & $\begin{array}{l}\text { A clinical } \\
\text { study }\end{array}$ & $\begin{array}{l}\text { Jusko et al., } \\
1979\end{array}$ \\
\hline Simvastatin & St John's wort & $\begin{array}{l}\text { Decreased Plasma } \\
\text { Digoxin conc. }\end{array}$ & $\begin{array}{l}\text { Simvastatin is a substrate } \\
\text { of P- glycoprotein and is } \\
\text { metabolized by CYP } \\
\text { enzymes. Both CYP } \\
\text { enzymes and P- } \\
\text { glycoprotein are induced } \\
\text { by St John's wort }\end{array}$ & $\begin{array}{l}\text { A clinical } \\
\text { study }\end{array}$ & $\begin{array}{l}\text { Kruth et al., } \\
2004\end{array}$ \\
\hline Phenprocoumon & $\begin{array}{l}\text { Ginger } \\
\text { St John's wort }\end{array}$ & $\begin{array}{l}\text { (i) Over- } \\
\text { anticoagulation } \\
\text { (ii) decreased } \\
\text { anticoagulant effect }\end{array}$ & $\begin{array}{l}\text { (i) Additive effect on } \\
\text { coagulation ( ginger } \\
\text { inhibits platelet } \\
\text { aggregation) } \\
\text { (ii)Phenprocoumon is } \\
\text { metabolized by } \\
\text { cytochrome enzymes } \\
\text { induced by St John's } \\
\text { wort. }\end{array}$ & $\begin{array}{l}\text { A clinical } \\
\text { study }\end{array}$ & $\begin{array}{l}\text { Yue and } \\
\text { Jansson, } 2001 \\
\text { Izzat et al., } 1998\end{array}$ \\
\hline Verapamil & St John's wort & $\begin{array}{l}\text { Decreased } \\
\text { bioavailability } \\
\text { of verapamil }\end{array}$ & $\begin{array}{l}\text { Induction of intestinal } \\
\text { CYP3A4 by St John's } \\
\text { wort. }\end{array}$ & $\begin{array}{l}\text { A clinical } \\
\text { study }\end{array}$ & Tam et al., 1995 \\
\hline Digoxin & $\begin{array}{l}\text { Gum guar, } \\
\text { St John’s } \\
\text { wort, Wheat } \\
\text { bran }\end{array}$ & $\begin{array}{l}\text { Decreased plasma } \\
\text { Digoxin } \\
\text { concentration }\end{array}$ & $\begin{array}{l}\text { (i) Gum guar delays } \\
\text { gastric emptying and } \\
\text { hence may reduce } \\
\text { digoxin absorption } \\
\text { (ii) St John's wort } \\
\text { induces P-glycoprotein } \\
\text { which is involved in } \\
\text { digoxin absorption/ } \\
\text { excretion } \\
\text { (iii) Fibres in bran may } \\
\text { trap digoxin in the gut. }\end{array}$ & $\begin{array}{l}\text { Clinical } \\
\text { studies }\end{array}$ & $\begin{array}{l}\text { Lee and } \\
\text { Stockley, 2003, } \\
\text { Lambrecht et al., } \\
2000, \\
\text { Cupp et al., } \\
\text { 1999, Chan et } \\
\text { al., 1995, } \\
\text { Wijnands et al., } \\
1987\end{array}$ \\
\hline
\end{tabular}




\begin{tabular}{|l|l|l|l|l|l|}
\hline Warfarin & Danshen & $\begin{array}{l}\text { Increase their risk } \\
\text { for bleeding. }\end{array}$ & $\begin{array}{l}\text { Additive effect due to } \\
\text { coumarin content in } \\
\text { danshen }\end{array}$ & $\begin{array}{l}\text { Case report } \\
1995, \text { Tam et al., } \\
\text { 1995, Yu et al., } \\
1997\end{array}$ \\
\hline Warfarin & Dong quai & $\begin{array}{l}\text { Increase their risk } \\
\text { for bleeding. }\end{array}$ & $\begin{array}{l}\text { Possible inhibition of } \\
\text { platelet activity by dong } \\
\text { quai }\end{array}$ & $\begin{array}{l}\text { Case report Woo et al., } \\
1995, \text { Lawrence } \\
\text { et al., 1999 }\end{array}$ \\
\hline Sodium valproate & $\begin{array}{l}\text { Ginkgo } \\
\text { biloba }\end{array}$ & $\begin{array}{l}\text { Decreased } \\
\text { bioavailability } \\
\text { of valproate } \\
\text { leaf/seed which may } \\
\text { contain neurotoxins }\end{array}$ & $\begin{array}{l}\text { Case report } \\
2001, \\
\text { Bebbington } \\
\text { al., 2005, } \\
\text { Mohutsky et al., } \\
2006\end{array}$ \\
\hline
\end{tabular}

\section{Drug interaction with herb}

When a drug is mixed with food or another herb, each can alter the way the body metabolizes the other. Some drugs interfere with the body's ability to absorb nutrients. Similarly, certain herbs and food can decrease or increase the impact of a drug.

- Alcohol interacts with almost every medication, especially antidepressant and other drugs that affect the brain and nervous system.

Some dietary components increase the risk of side effects. Theophylline, administered to treat asthma, contains xanthenes, which is also present in tea, coffee, chocolate and other sources of caffeine. Consuming large amount of such substances, with theophylline increases the risk of toxicity.

- Dietary fiber affects drug absorption. Pectin and other soluble fibers slow down the absorption of acetaminophen, a popular painkiller. Bran and other insoluble fibers have a similar effect on digoxin, a major cardiac medication.

With new herbs, there is increased potential for its abuse and the patients may end up with serious problems. High-risk patients, such as the elderly on multiple medications for chronic conditions, patients suffering from diabetes, hypertension, depression, high cholesterol or congestive heart failure should be alerted against such reactions.

\section{Examples of interaction among herb, food, prescription, non prescription/over the counter drugs:}

Hawthorn effective in reducing angina attack, by lowering blood pressure and cholesterol level, should never be taken along with Lanoxin (digoxin), commonly prescribed for cardiac ailments. The combination can lower heart rate, causing blood to pool, resulting in possible cardiac failure.

Ginseng according to research could increase blood pressure, so is not advisable in patients with hypertension. Ginseng, garlic or supplements containing ginger, when taken with the blood-thinning drug Coumadin, could cause bleeding episodes. In some cases, ginseng may over stimulate and result in insomnia. Caffeine and ginseng combination increases the risk of overstimulation and gastrointestinal upset. Long term use of ginseng may cause menstrual abnormalities and breast tenderness in some women. Ginseng is not advisable for pregnant or lactating women.

Garlic containing herbal capsules when combined with diabetes medication could cause dangerous decrease in blood sugar level. Some garlic sensitive individuals may experience heart burn and flatulence. Garlic has anti-clotting properties; one should consult the doctor before taking any anticoagulant drug.

Goldenseal is often used for cough, stomach upset, arthritis and menstrual problem. However, this plant's active ingredients raises blood pressure, which could interfere with treatment of those on antihypertensive medication especially beta-blocker. This herb can also cause dangerous electrolyte imbalance in patients suffering from diabetes or kidney disorders. Consumption in heavy doses could lead to gastrointestinal distress and nervous system abnormalities. It is not recommended for pregnant and lactating women.

Feverfew believed to be the natural remedy for migraine, should never be taken with Imitrex or other migraine medication. It could result in elevated blood pressures and heart-rate.

Guarana an alternative remedy as stimulant and dietary aid, contains 3\% to 5\% more caffeine than that present in a cup of coffee. It may cause insomnia, trembling, anxiety, palpitations, urinary frequency and hyperactivity. It should be avoided during 
pregnancy and lactation. Long term use of Guarana may lead to decreased fertility, cardiovascular disease and several forms of cancer.

Kava has antianxiety, pain relieving, muscle relaxing and anticonvulsant effects. It should not be taken with central nervous system stimulants such as alcohol, barbiturates, antidepressants, and antipsychotic drugs.

St. John's Wort is a popular herb for the treatment of mild depression. Its active ingredient hypericin is believed to exert similar effect on the brain as the monoamine oxidase (MAO) inhibitors. Taking MAO inhibitors with food rich in tyramine (an amino acid) produces dramatic food-drug interaction. Foods rich in tyramine include chicken liver, yeast extracts, dried or pickled fish, legumes, soy sauce and beer. Symptoms of such interaction include rapid rise in blood pressure, severe headache which may lead to even death. This herb in some patients caused excessive stimulation, dizziness and agitation with certain anti-depressants and OTC medication like Dexatrim and Acutrim. (Aga et al., 2003).

\section{Drug interaction with food}

Drug interaction risk is not limited to herbal supplements. People taking digoxin should avoid black licorice as it contains glycyrrhizin. Together they interact to produce irregular heart rhythms and cardiac arrest. Licorice and diuretics lower the potassium levels, cause numbness weakness, muscle pain and even paralysis. (Sorensen et al., 2002).

Grapefruit juice interact with calcium channel blockers such as Calan, Procardia, Nifedipine, and Verapamil, anti-psychiatric medication, estrogen, oral contraceptive and certain anti-allergic drugs such as Seldane, Hismanal.

Orange juice must not be consumed with antacids containing aluminum. The juice increases the absorption of aluminum and leads to severe constipation. Orange Juice and milk should be avoided with taking antibiotics, as they decrease its effectiveness. Milk contains elements like Mg and Ca which chetate antibiotics like tetracycline and hence decrease its absorption and effect.

Milk does not mix with laxatives which contain bisacodyl (Correctol and Dulcolax). Large amount of oatmeal and other highfiber cereals should not be eaten with digoxin, as it interferes with drug absorption. A professional expert could recommend dietary changes after carefully examining the digoxin levels.

Leafy green vegetables high in vitamin K content should not be consumed with Coumadin, as it negates the effects of the drug and can lead to blood clotting.

Caffeinated beverages and antiasthmatic drugs or quinolone antibiotics such as Cipro, penetrex, noroxin and oral contraceptives taken together can cause excessive excitability. (Shannon et al., 1997).

Grilled meat can lead to severe problems for those on asthmatic medication containing theophylline as its interaction, increases the possibility of an unmanageable asthmatic attack. Regular consumption of diet rich in fat, with anti-inflammatory and antiarthritic drugs can cause kidney damage.

Alcoholic beverages tend to increase the depressive effect of medications such as benzodiazepines, antihistamines, antidepressants, antipsychotics, muscle relaxants, narcotics, or any drug with sedative actions. Antioxidants and beta-carotene intensify the effect of alcohol on the liver. (Barone et al., 2001).

Tomato contains small quantity of a toxic substance known as solanine that may trigger headache in certain individuals. An unidentified constituent in tomato and tomato-based products can cause acid reflux, leading to indigestion and heartburn.

Strawberry, raspberry, spinach and rhubarb contain oxalic acid, which can aggravate kidney and bladder stones in susceptible individuals and reduce ability to absorb iron and calcium. Raspberries contain a natural salicylate which can cause allergic reaction in aspirin sensitive individuals.

Potato especially the unripe and with a green tint in skin contain solanine, a toxic substance that can lead to diarrhea, cramps, and fatigue.

Plums, peaches, apricots and cherries may produce allergic reaction in certain individuals, as it contains salicylates. The pits of plums, peaches and apricots contain a compound called amygdalin. When consumed in large amounts, amygdalin breaks down to form hydrogen cyanide which causes poisoning.

\section{How to minimise drug interactions}

Some broad principles may help prescribers to minimize risk of drug interaction to the patients.

- Beware with drugs with narrow therapeutic window e.g. anticoagulants, anticonvulsive drugs. 
- Be aware with drugs which are enzyme inducers or inhibitors.

- Consider drug pharmacology to avoid pharmacodynamic interaction with drugs, herbal and food supplements.

- Avoid multiple drug combination (especially those involving NSAIDS) if risks outweigh the benefits.

- High alert while prescribing for elderly or chronically ill patients.

\section{Limitations}

Much of the available information on interaction between herbal products and prescribed drugs is gleaned from case reports, although clinical studies are now also beginning to appear in the literature. The published case reports are often incomplete. According to the scoring system described by Fugh-Berman and Ernst (Fugh-Berman et al., 2001), 68.5\% of the cases reported were classified as 'invaluable' as they contained inadequate information to assess the likelihood of an interaction, $18.5 \%$ were classified as 'possible' as they provided some evidence of interaction and $13 \%$ as 'well documented' when they provided reliable evidence of interaction.

\section{Conclusion}

Contrary to popular belief that "natural drugs are safe", herbal medicines can cause significant toxic effects, drug interaction and even incidences of morbidity or mortality. This article is not against herbal medicines. Based on evidence from in vitro, in vivo and clinical studies, herbal and other dietary supplements have shown interaction with many drugs. Still many drugherbal interactions are difficult to evaluate. Physicians must indulge in patient counseling to avoid risks of drug interaction with herbal supplements. The interaction often involves drug-metabolizing enzymes and drug transporter systems, besides pharmacodynamic interaction. Since the pharmacokinetic and pharmacodynamic characteristics of most herbal and other dietary supplements are not completely recognized, potential interactions are often not predictable. Potential interactions are likely to occur with drugs with narrow therapeutic index. The evidence based evaluation used in the study can be used to evaluate reliability of the case reports.

\section{Acknowledgement}

We are grateful to the Dr. K.F.H. Nazeer Ahamed, Assistant Professor, department of pharmacology, Vel's college of pharmacy, Chennai, for his assistance and encouragement. We extend our sincere thanks to Mrs. Saba Ansari, research scholar, department of Pharmacognosy \& Phytochemistry, Faculty of pharmacy, Integral University,Lucknow, for critically reading the manuscript and providing the valuable suggestions.

\section{References}

1. Agrawal, O. P. and Raju, P.S. (2006). Traditional system of medicine. In: Abdin MZ and Abroi YP. (Eds.) Global Market of Herbal Products: Opportunities for India. Narosa Publishing House, New Delhi, India, 5- 10.

2. Smith, M. (2000). Drug interactions with natural health products/dietary supplements: a survival guide. Paper presented at Complementary and Alternative Medicine: Implications for Clinical Practice and State-of-the-Science, Symposia, 2000 March 12, Boston, Mass.

3. Eisenberg, D. M., Davis, R. B. and Ettner, S. L. (1998). Trends in alternative medicine use in the United States, 1990-1997: results of a follow-up national survey. JAMA. 280, 1569-75.

4. Kaptchuk, T. J. and Eisenberg D. M. (1998). The persuasive appeal of alternative medicine. Ann. Intern. Med. 129, $1061-65$.

5. Schultz, V., Hansel, R., and Tyler, V. E. (1998). Rational Phytotherapy: A Physician's Guide to Herbal Medicine. Berlin, Springer-Verlag.

6. Ernst, E. (2000). Possible interactions between synthetic and herbal medicinal products. Part 1: a systematic review of the indirect evidence. Perfusion. 13, 2200-2211.

7. Izzo A. A. (2004). Drug interactions with St. John's wort (Hypericum perforatum): a review of the clinical evidence. Int. J. Clin. Pharmacol. Ther. 42, 139-148.

8. Marechal1, J. D., Kemp C. A., Roberts, G. C. K., Paine, M. J. I., Wolf, C. R. and Sutcliffe M. J. (2008). Insights into drug metabolism by cytochromes P450 from modelling studies of CYP2D6-drug interactions. B. J. Pharmacol. 153, S82-89.

9. Jacobs, B. P., Dennehy, C., Ramirez, G. J., Sapp and Lawrence, V. A. (2002). Milk thistle for the treatment of liver disease: a systematic review and metaanalysis. Amer. J. Med. 113, 506-515.

10. Rodriguez-Landa, J. F. and Contreras C. M. (2003). A review of clinical and experimental observations about antidepressant actions and side effects produced by Hypericum perforatum extracts. Phytomedicine. 10, 688-699.

11. Chavez, M. L., Jordan, M. A., Chavez, P. I. (2006). Evidence-based drug-herbal interactions. Life Sciences. 78. $2146-2157$

12. Linde, K., Ramirez, G., Mulrow, C. D., Pauls, A., Weidenhammer, W. and Melchart D. (1996). St John's wort for depression-an overview and meta-analysis of randomised clinical trials. BM. J. 313, 253-258.

13. Wheatley, D. (1997). LI 160, an extract of St. John's wort, versus amitriptyline in mildly to moderately depressed outpatients-a controlled 6-week clinical trial. Pharma. Psychiatry. 30, 77-80.

14. Hussain, M. S., Ansari, M. Z. H., Arif, M. (2009). Hyperforin: A lead for Antidepressants. Inter. J. Hea Res. 2(1), 15-22. 
15. Nathan, P. (1999). The experimental and clinical pharmacology of St John's wort (Hypericum perforatum L.). Mol. Psychiatry. 4, 333-338.

16. Dewick, P. M. (1997). The biosynthesis of C5-C25 terpenoid compounds. National Productivity Report. 14, 111-144.

17. Wagner, H. (1986). Antihepatotoxic flavonoids. Prog in Clin. and Biol. Res. 213, 545-558.

18. Foster Steven and Tyler, V. E. (1999). Tyler's honest herbal: a sensible guide to the use of herbs and related remedies. Xxi, 1999, pp 442.

19. Schulz Volker., Hèansel Rudolf and Tyler, V. E. (2001). Rational phytotherapy: a physician's guide to herbal medicine. Xix, 383 pp.

20. Paul, R. and Ortiz, de Montellano (1996). Cytochrome P450: Structure, mechanism and biochemistry. $3^{\text {rd }}$ ed, 35, 4540.

21. Meunier, B., De Visser S. P and Shaik S. (2004). Mechanism of oxidation reactions catalyzed by cytochrome P450 enzymes. Chem. Rev. 104, 3947-80.

22. Werck-Reichhart, D and Feyereisen R. (2000). Cytochromes P450: a success story. 1(6), Reviews 3003.

23. Degtyarenko, K. N. (1995). Structural domains of P450-containing monooxygenase systems. Protein Eng. 8 (8), 737-47.

24. Guengerich, F. P. (2006). Cytochrome P450s and other enzymes in drug metabolism and toxicity. AAPS. J. 8 (1), E101-11.

25. Guengerich, F. P. (1997). Role of cytochrome P450 enzymes in drug-drug interactions. Adv. Pharmacol. 43, 7-35.

26. Munasinghe, T. M. (2002). Adverse drug reactions: monitoring, reporting and prevention. Ceylon. Med. J. 47(1), 19-21.

27. Glue, P and Clement, R. P. (1999). Cytochrome P450 enzymes and drug metabolism-basic concepts and methods of assessment. Mol. Neurobiol. 19 (3), 309-23.

28. Robertson, S. M., Penzak, S. R and Pau, A. K. (2005). Drug interactions in the management of HIV infection. Expert Opin. Pharmacother. 6, 233-53.

29. Warrington, J. S. and Shaw L. M. (2005). Pharmacogenetic differences and drug-drug interactions in immunosuppressive therapy. Expert Opin. Drug Metab. Toxicol. 1, 487-503.

30. Stockley, I. H. (2002). Stockley's drug interactions, $6^{\text {th }}$ ed. London: pharmaceutical Press.

31. Grenier, L. (2003). Less interactions medicamenteuses. In: L. Mallet, Grenier, L., Guimond, J., Barbeau, G., eds. Manuel de soins pharmaceutiques en gériatrie. Québec: Presses Del’Université de Laval. 131-52.

32. Nebert, D. W. and Russell D. W. (2002). Clinical importance of the cytochromes P450. Lancet. 360, 1155-62.

33. Christians, U. V. Schmitz and Haschke, M. (2005). Functional interactions between P-glycoprotein and CYP3A in drug metabolism. Expert. Opin. Drug Metab. Toxicol. 1, 641-54.

34. Bista, D., Palaian, S., Shankar, P. R., Prabhu, M. M., Paudel, R. and Mishra, P. (2006). Understanding the essentials of drug interactions: A potential need for safe and effective use of drugs. Kath. Univ. Med. J. 4 (3), 421-430.

35. Lee, A and Stockley, I. H. (2003). Drug interactions In Walker R, Edwards C. Clinical Pharmacy and Therapeutics. $3^{\text {rd }}$ ed. Churchill Livingstone, Philadelphia. 21-31.

36. Lambrecht, J. E., Hamilton W. and Rabinovich A. (2000). A Review of Herb-Drug Interactions: Documented and Theoretical. US Pharmacist. 25 (8), 42-53.

37. Cupp, M. J. (1999). Herbal Remedies: adverse effects and drug interactions. Am. Fam. Physician. 59 (5), 1239-45.

38. Chan, T. Y. K. (1995). Adverse interactions between warfarin and nonsteroidal anti-inflammatory drugs: mechanisms, clinical significance, and avoidance. Ann. Pharmacother. 29, 1274-83.

39. Wijnands, W. J. A., Vree, T. B. and Baars, A. M. (1987). Steady state kinetics of the quinolone derivatives ofloxacin, enoxacin, ciprofloxacin, and perfloxacin during maintenance treatment with theophylline. Drugs. 34 (1), 159-69.

40. Leon, A. S., Spiegel, H. E. and Thomas, G. (1971). Pyridoxine antagonism of levodopa in Parkinsonism. JAMA. 218,1924 -7.

41. Jusko, W. J. (1979). Influence of cigarette smoking on drug metabolism in man. Drug. Metab. Rev. 9, 221-36.

42. Kruth, P., Brosi, E., Fux, R., Morike, K. and Gleiter, C. H. (2004). Ginger associated over anticoagulation by phenprocoumon. Ann. Pharmacother. 38, 257-260.

43. Yue, Q. Y. and Jansson K. (2001). Herbal drug curbicin and anticoagulant effect with and without warfarin: possibly related to the vitamin E component. J. Am. Geriatr. Soc. 49(6), 838.

44. Izzat, M. B., Yim, A. P. and El-Zufari, M. H. (1998). A taste of Chinese medicine. Ann. Thorac. Surg. 66, 941-942.

45. Tam, L. S., Chan, T. Y., Leung, W. K., and Critchley, J. A. (1995). Warfarin interactions with Chinese traditional medicines: danshen and methyl salicylate medicated oil. Aust. N Z. J. Med. 225-238.

46. Jiang, X., Williams, K. M., Liauw W. S. (2004). Effect of St John's wort and ginseng on the pharmacokinetics and pharmacodynamics of warfarin in healthy subjects. Br. J. Clin. Pharmacol. 57, 592-599.

47. Meisel, C., Johne, A., Roots, I. (2003). Fatal intracerebral mass bleeding associated with Ginkgo biloba and ibuprofen. Atherosclerosis 167(2): 367.

48. Legnani, C., Frascaro, M., Gauzzaloca, G. (1993). Effects of a dried garlic preparation on fibrinolysis and platelet aggregation in healthy subjects. Arzneimittelforschung; 43(2), 119-22.

49. Vuksan, V., Stavro, S. P., Sievenpiper, J. L. (2000). Similar postprandial glycemic reductions with escalation of dose and administration time of American ginseng in type 2 diabetes. Diabetes Care. 23(9), 1221-26.

50. Hennessy, M., Kelleher, D., Spiers, J. P. (2002). St. John's Wort increases expression of Pglycoprotein: implications for drug interactions. Br. J. Clin. Pharmacol. 53(1), 75-82.

51. Cupp, M. J. (1999). Herbal Remedies: adverse effects and drug interactions. Am. Fam. Physician. 59(5), 1239-45.

52. Westendorf, J. Anthranoid derivatives-general discussion. In: DeSmet PAGM, et al, eds. (1993). Adverse Effects of Herbal Drugs. Berlin: Springer. 2, 105-118. 
53. Mu, Y., Zhang, J., Zhang, S., Zhou, HH., Toma, D., Ren, S., Huang, L., Yaramus, M., Baum, A., Venkataramanan, R., Xie, W. (2006) Traditional Chinese medicines Wu Wei Zi (Schisandra chinensis Baill) and Gan Cao (Glycyrrhiza uralensis Fisch) activate pregnane $X$ receptor and increase warfarin clearance in rats. J. Pharmacol. Exp. Ther. 316, 1369-1377.

54. Gaddis, G. M., Holt, T. R., Woods, M. (2002). Drug interactions in at-risk emergency department patients. Acad. Emerg. Med. 9, 1162-7.

55. Schmider, J. and Brockmoller, J. (2002). Decreased plasma levels of amitriptyline and its metabolites on comedication with an extract from St. John's wort (Hypericum perforatum). J. Clin. Psychopharmacol. 22, 46-54.

56. Dannawi, M. (2002). Possible serotonin syndrome after combination of buspirone and St John's wort. J. Psychopharmacol. 16 (4), 401.

57. Gorski, J. C., Huang S. M. and Pinto A. (2004). The effect of Echinacea (Echinacea purpurea) root on cytochrome P450 activity in vivo. Clin. Pharmacol. Ther. 89-100.

58. Mohammad, Y. M. I. (2009). Herb-drug interactions and patient counseling. Inter. J. Pharm \& Pharm. Sci. 1, $151-161$.

59. Chan, K., Lo, A. C., Yeung J. H. and Woo, K. S. (1995). The effects of danshen (Salvia miltiorrhiza) on warfarin pharmacodynamics and pharmacokinetics of warfarin enantiomers in rats. J. Pharm. Pharmacol. 47(5), 402-406.

60. Tam, L. S., Chan, T. Y., Leung, W. K. and Critchley, J. A. (1995). Warfarin interactions with Chinese traditional medicines: danshen and methyl salicylate medicated oil. Aust. N Z. J. Med. 25(3), 258.

61. Yu, C. M., Chan, J. C. and Sanderson J. E., (1997). Chinese herbs and warfarin potentiation by 'Danshen’. J. Intern. Med. 241(4), 337-339.

62. Lo, A. C., Chan, K., Yeung J. H. and Woo, K. S. (1995). Danggui (Angelica sinensis) affects the pharmacodynamics but not the pharmacokinetics of warfarin in rabbits. Eur. J. Drug. Met. Pharmacokinet. 20(1), 55-60.

63. Page, R. L. and Lawrence, J. D. (1999). Potentiation of warfarin by dong quai. Pharmacotherapy. 19(7), 870-876.

64. Granger, A. S. (2001). Ginkgo biloba precipitating epileptic seizures. Age Ageing. 30 (6), 523-525.

65. Bebbington, A., Kulkarni, R., Roberts, P. (2005). Ginkgo biloba: Persistent bleeding after total hip arthroplasty caused by herbal self-medication. J. Arthroplasty 20, 125-6.

66. Mohutsky, M. A, Anderson, G. D, Miller, J. W, Elmer, G. W. (2006). Ginkgo biloba: evaluation of CYP2C9 drug interactions in vitro and in vivo. Am. J. Ther. 13:24-31.

67. Boullata, J. (2005). Natural health product interaction with medication. Nutr. Clin. Pract. 20 (1), 33-51.

68. Hussain, S. H. (1999). Potential risks of health supplements- self-medication practices and the need for public health education. Int. J. Risk. Saf. Med. 12, 167-71.

69. Dietry Supplement-A Framework for Evaluating Safety, Institute of Medicine. National Academic Press 2005; Pp 235-246. http://www.nap.edu/book/0309091101/html(accessed August 31, 2005).

70. Izzo, A. A. (2005). Herb-drug interactions: an overview of the clinical evidence. Fund \& Clin. Pharmacol. 19(1), 1 - 16.

71. Anon, 2002. Center for drug evaluation and research 2002. Report to the nation. Improving public health through human drugs. U.S. Department of Health and Human Services. Food and Drug Administration Center for Drug Evaluation and Research. http://www.fda.gov/reports/rtn/2002.Ptn2002.pdf.Accessed February 2, 2005.

72. Anon, 2001. Office of Inspector General, Department of Health and Human Services. Adverse event reporting for dietary supplements: an inadequate safety valve. April 2001, http://oig.hhs.gov/oei/reports/oei-01-00-00180. pdf. Accessed December 21, 2004.

73. Barnes, J., Mills, S. Y. and Abbott, N. C. (1998). Different standards for reporting ADRs to herbal remedies and conventional OTC medicines: face to face interviews with 515 users of herbal remedies. Br. J. Clin. Pharmacol. 45, 496-500.

74. Fugh-Berman, A.and Ernst, E. (2001). Herb-drug interactions: review and assessment of report reliability. Br. J. Clin. Pharmacol. 52, 587-595.

75. Sorensen, J. M. (2002). Herb-drug, food-drug, nutrient-drug, and drug-drug interactions: mechanisms involved and their medical implications. J. Altern. Complement. Med. 8, 293-308.

76. Shannon, M. (1997). Drug-drug interactions and the cytochrome P450 system: an update. Pediatr. Emerg. Care. 13, $3502-3$.

77. Barone, G. W., Gurley, B. J., Ketel B. L., Abul-Ezz, S. R. (2001). Herbal supplements: a potential for drug interactions in transplant recipients. Transplantation. 71, $239-241$.

78. Aga, V. M., Barklage, N.E., Jefferson, J. W. Linezolid. (2003). A monoamine oxidase inhibiting antibiotic, and antidepressants. J. Clin. Psychiatry. 64, 6092-11. 